\title{
In Vitro Evaluation of Antimicrobial Activity of Lactobacillus Rhamnosus: Extracts Against Pathogens Causing Wound Infection
}

\author{
Mridula G Nair \\ R. K. Talreja College, Ulhasnagar, Department of Microbiology \\ mridunair17@gmail.com
}

\begin{abstract}
A break or wound in the skin makes a favourable environment for the invasion of bacterial pathogens. Variety of Gram positive and Gram-negative organisms cause wound infection. Conventional drugs have been used to treat them, but their overuse has led to an increase in development of MDR pathogens. Thus, it has become the need of the hour to develop newer drugs to treat them preferably without the pathogens developing resistance against them. Moringa oleifera Lam. has been used since ages for treating various diseases. It is a rich source of variety of phytochemicals and can serve as a potential therapeutic agent. Wound pathogens were isolated from samples collected from open wound lesions of patients from Central hospital, Ulhasnagar. Pathogens were isolated and identified on the basis of Bergey's manual. Presence of MDR was confirmed by antibiotic Disc diffusion test. The leaves bark and seeds of Moringa oleifera Lam. were used to prepare acetone and aqueous extracts. In vitro antimicrobial activity was evaluated qualitatively by Agar ditch plate method and quantitatively by Agar dilution method. Among the isolates there was a high prevalence of Gramnegative pathogens (70\%). Staphylococcus spp. were predominant in Gram positive isolates (20\%). Of total isolates, $20 \%$ were MDR pathogens. There was high amount of glycosides present in different extracts of Moringa oleifera Lam. followed by tannins and flavonoids in both acetonic and aqueous extracts. The aqueous leaf extract had broad spectrum and the highest antibacterial activity.
\end{abstract}

Keywords: wound infection, Moringa oleifera Lam., antimicrobial, phytochemicals

\section{Introduction}

A discontinuity in the skin due to injury can weaken its defence mechanisms, thereby making the surrounding more favourable for invasion and proliferation of bacteria. The process of wound healing may be hampered by microbial infection ${ }^{1}$.Common bacterial pathogens associated with wound infection include Staphylococcus aureus, Escherichia coli, Pseudomonas aeruginosa, Klebsiella pneumoniae, Streptococcus pyogenes, Proteus species, Streptococcus species, and Enterococcus species ${ }^{2}$. The control of wound infections has become more challenging due to widespread bacterial resistance to antibiotics ${ }^{3}$.

Throughout the ages, plants have been a valuable resource of natural products for human health. Studies have shown the presence of different phytochemical constituents in botanical sample responsible for the antimicrobial activity ${ }^{4}$. Moreover, several natural products obtained from medicinal plants lead to the development of various pharmaceuticals and analogues or derivatives ${ }^{5}$.

Moringa oleifera Lam. is most widely cultivated species of a monogeneric family, the Moringaceae ${ }^{6}$.Majority of the phytochemicals like polyphenols, carotenoids, alkaloids, terpenoids, and sulphur containing compounds are also present in Moringa tree ${ }^{7}$. Traditionally, Moringaoleifera Lam. has been used in the treatment of infected wounds ${ }^{1}$.Various parts of the plant are known to possess significant antibacterial activity as well as wound healing properties. The present study aims at evaluating the in vitro antimicrobial activity of various extracts of Moringa against pathogens causing wound infection.

\section{Materials and methods}

Sample collection, isolation and identification:

Pathological samples were collected from open wound lesions of patients in Central Hospital, Ulhasnagar. The samples were then isolated on SIBA, Nutrient agar and MacConkey agar. Various isolates obtained from wound were further identified on the basis of cultural, morphological and biochemical tests ${ }^{8}$.

In vitro antibiotic susceptibility testing of the isolates ${ }^{9}$ In vitro susceptibility testing was performed by Kirby-Bauer disk diffusion technique for all the pathogenic wound isolates. For Gram-positive bacteria following antibiotics were used- Gentamycin (30mcg), Ciprofloxacin (10mcg), Erythromycin $(5 \mathrm{mcg})$ and Oxacillin $(5 \mathrm{mcg})$.

For Gram-negative pathogens Gentamycin (30mcg), Ciprofloxacin (10mcg), Amikacin (10mcg) and Ampicillin (10mcg) were used; for Pseudomonas spp. all antibiotics except Ampicillin was replaced by Cephotaxime (30mcg).

Collection and preparation of Moringa extracts:

Leaves, bark and seeds of Moringa oleifera Lam. were collected and air dried, then ground to fine powder. Acetonic extracts were prepared by carrying out extraction in Soxhlet apparatus. Aqueous extract was prepared by using boiling water bath. After extraction, the extract was dried at appropriate temperature. For further studies, the dried extract obtained was dissolved in suitable amount of distilled water and used.

Phytochemical Analysis of the extracts ${ }^{10,11,12}$ :

Chemical analysis for phytochemicals was done to examine the presence of various phytochemical constituents like 
alkaloids, tannins, chelated phenols, steroids, flavonoids, fatty acids and saponins.

\section{Determination of in vitro antimicrobial activity of the extracts:}

\section{A) Qualitative analysis (Ditch plate method).}

Four standard test cultures namely $S$. aureus, E. coli, Klebsiella pneumoniae and Pseudomonas aeruginosa were used.

\section{B) Quantitative analysis (Agar dilution method) ${ }^{13}$}

Plates with varying concentrations of acetone and aqueous extracts of Moringa leaves, seeds and bark were prepared and $24 \mathrm{hr}$ old cell suspension of isolated wound pathogens were tested by grid plate method. The MIC was then determined for each isolate as the lowest concentration of test extract preventing the growth.

\section{Results and discussion}

Isolation and identification of bacterial pathogens from the wound samples:

Total 30 isolates were identified from different types of wound samples like accident wounds, insect bites, injury etc. Of the 30 isolates obtained from the wound samples (as in Table 1), Gram negative rods were more prevalent. The most common pathogen causing wound infection was Staphylococcus spp. (20\%), followed by Kluyvera spp. (16.67\%) and the least being Streptococcus spp. (10\%). There was higher prevalence of Kluyvera spp. among all the Gram-negative isolates but Staphylococcus spp. was the predominant Gram-positive pathogen from the wound samples.

Table 1: Different bacterial pathogens identified from wound samples

\begin{tabular}{|c|c|c|c|}
\hline \multicolumn{2}{|c|}{ Organism } & \begin{tabular}{|c|} 
Total \\
organisms
\end{tabular} & $\begin{array}{c}\text { Total } \\
\text { Percentage }(\%)\end{array}$ \\
\hline \multirow{2}{*}{$\begin{array}{c}\text { Gram positive } \\
n=9(30 \%)\end{array}$} & Staphylococcus spp. & 6 & 20 \\
\hline & Streptococcus spp. & 3 & 10 \\
\hline \multirow{5}{*}{$\begin{array}{c}\text { Gram negative } \\
n=21 \\
(70 \%)\end{array}$} & Escherichia spp. & 4 & 13.33 \\
\hline & Klebsiella spp & 4 & 13.33 \\
\hline & Proteus spp & 4 & 13.33 \\
\hline & Pseudomonas spp & 4 & 13.33 \\
\hline & Kluyveraspp & 5 & 16.67 \\
\hline \multicolumn{2}{|c|}{ Total $(\mathrm{N})$} & 30 & 100 \\
\hline
\end{tabular}

Mama M et al. ${ }^{14}$ in 2014 and Mohammad A et al., ${ }^{2}$ in 2017 reported that Gram negative wound pathogens were commonly isolated from the wound infections. Egbe C A et al. ${ }^{3}$ (2011), Mama M et al., ${ }^{14}$ (2014) and Mohammad A et al., ${ }^{2}$ (2017) have also reported the highest prevalence of Staphylococcus spp. in wound infections. Egbe C A et al., ${ }^{3}$ (2011) that Streptococcus spp. was the least prevalent etiological agent in wound infections.

In vitro antibiotic susceptibility of the bacterial isolates (Kirby-Bauer disk diffusion method) ${ }^{9}$
The highest resistance among all Gram-positive pathogens was towards Erythromycin (100\%). There were no MDR detected among Staphylococcus species. Though percentage of Streptococcus spp. was the least among the Gram positive isolates, there were more MDR in Streptococcus spp. $(3.33 \%)$.

Among Gram-negative pathogens, maximum resistance was against Ampicillin, and in case of Pseudomonas spp. resistance was higher towards Cephotaxime. Among both Gram-positive and Gram-negative pathogens, the highest sensitivity was towards Gentamycin. MDR pathogens were predominant among Gram-negative pathogens and maximum MDR were from Proteus spp. and Pseudomonas spp.

The number of multiple drug resistant pathogen among the wound isolates were as depicted in Table 2.

Table 2: Number of multiple drug resistant (MDR) pathogens isolated from wound sample

\begin{tabular}{|c|c|c|}
\hline \multicolumn{2}{|r|}{ Organism } & Total no. of MDR (\%) \\
\hline \multirow{2}{*}{$\begin{array}{l}\text { Gram } \\
\text { positive } \\
\text { isolates }\end{array}$} & $\begin{array}{c}\text { Staphylococcus spp. } \\
(\mathrm{n}=6)\end{array}$ & $(0 \%)$ \\
\hline & $\begin{array}{c}\text { Streptococcus spp. } \\
(\mathrm{n}=3)\end{array}$ & $\begin{array}{c}1 \\
(3.33 \%)\end{array}$ \\
\hline \multirow{5}{*}{$\begin{array}{l}\text { Gram } \\
\text { negative } \\
\text { isolates }\end{array}$} & $\begin{array}{c}\text { Escherichia spp. } \\
(\mathrm{n}=4)\end{array}$ & $\begin{array}{c}- \\
(0 \%)\end{array}$ \\
\hline & $\begin{array}{c}\text { Klebsiella spp. } \\
(\mathrm{n}=4)\end{array}$ & $\begin{array}{c}1 \\
(3.33 \%) \\
\end{array}$ \\
\hline & $\begin{array}{c}\text { Proteus spp. } \\
(\mathrm{n}=4)\end{array}$ & $\begin{array}{c}2 \\
(6.67 \%)\end{array}$ \\
\hline & $\begin{array}{c}\text { Pseudomonas spp. } \\
(\mathrm{n}=4)\end{array}$ & $\begin{array}{c}2 \\
(6.67 \%) \\
\end{array}$ \\
\hline & $\begin{array}{c}\text { Kluyvera spp. } \\
(\mathrm{n}=5)\end{array}$ & $\begin{array}{c}- \\
(0 \%)\end{array}$ \\
\hline \multicolumn{2}{|c|}{ Total $(\mathrm{N}=30)$} & $\begin{array}{c}6 \\
(20 \%)\end{array}$ \\
\hline
\end{tabular}

Mohammad A et al., ${ }^{2}$ (2017), Mama M et al., ${ }^{12}$ (2014) and Taiwo S S et al., ${ }^{15}$ (2011) have reported that Staphylococcus spp. exhibited maximum sensitivity towards Gentamycin. Maximum sensitivity of the Gram-negative isolates to Gentamycin was reported by Mohammad A et al., ${ }^{2}(2017)$ and Mordi R M et al., ${ }^{16}$ (2009). Mehta M et al., ${ }^{14}$ (2007) and Bessa L J et al., ${ }^{17}$ (2013), their studies showed significantly high resistance of Pseudomonas spp. towards the drug Cephotaxime. Mama M et al., ${ }_{14}$ (2014), Mohammad A et al., ${ }^{2}$ (2017) and Fantahun B et al., 18 (2009) have reported a very high percentage of MDR pathogens in the wound infections.

Phytochemical analysis of the extracts ${ }^{10,11,12}$ :

The acetone and aqueous extracts of the leaves, seeds and bark were checked for the presence of phytochemicals. The phytochemical analysis of various extracts was as depicted in Table 3. Among all the phytochemicals, glycosides were present in most of the extracts, followed by tannins and flavonoids, whereas alkaloids and saponins were absent in all. 
Table 3: Phytochemicals present in the extracts

Key: + present; - absent

\begin{tabular}{|c|c|c|c|c|c|c|c|}
\hline \multicolumn{2}{|c|}{ Extracts } & \multicolumn{7}{c|}{ Phytochemicals } \\
\cline { 3 - 9 } & & Tannins & Proteins & Saponins & Alkaloids & Glycosides & Flavonoids \\
\hline \multirow{3}{*}{ Acetone } & Seed & - & - & - & - & + & - \\
\cline { 2 - 8 } & Bark & + & - & - & - & + & + \\
\cline { 2 - 8 } & Leaf & + & - & - & - & - & - \\
\hline \multirow{3}{*}{ Aqueous } & Seed & - & - & - & - & + & + \\
\cline { 2 - 8 } & Bark & - & - & - & - & + & - \\
\cline { 2 - 8 } & Leaf & + & + & - & - & + & - \\
\hline
\end{tabular}

Padmalochana $\mathrm{K}^{19}$ (2018) reported presence of tannins in acetonic leaf extracts. Absence of glycosides in the acetonic seed extract was reported by reported by Javed $\mathrm{K} \mathrm{Z}^{20}$ (2018). Rathi B et al., ${ }^{21}$ (2004) reported presence of presence of glycosides in the aqueous seed extract. Vinoth B et al., ${ }^{22}$ (2012) studies showed the presence of glycosides and tannins in the aqueous leaf extract.

Determination of in vitro antimicrobial activity of the extracts:

\section{A) Qualitative analysis (Ditch Plate method)}

Various extracts were tested for their antimicrobial activity using ditch plate method. Aqueous extract of leaf had broad spectrum activity inhibiting both Gram-positive and Gramnegative bacteria. Comparatively, acetonic extracts of seed and bark had narrow spectrum activity.

\section{B) Quantitative analysis (Agar dilution method)}

Minimum inhibitory concentration (MIC) of the different extracts was determined by agar dilution method for different wound isolates as given in Table 4.

Significant antimicrobial activity was seen in case of the aqueous leaf extract compared to acetonic bark extract as shown in Figure 1.

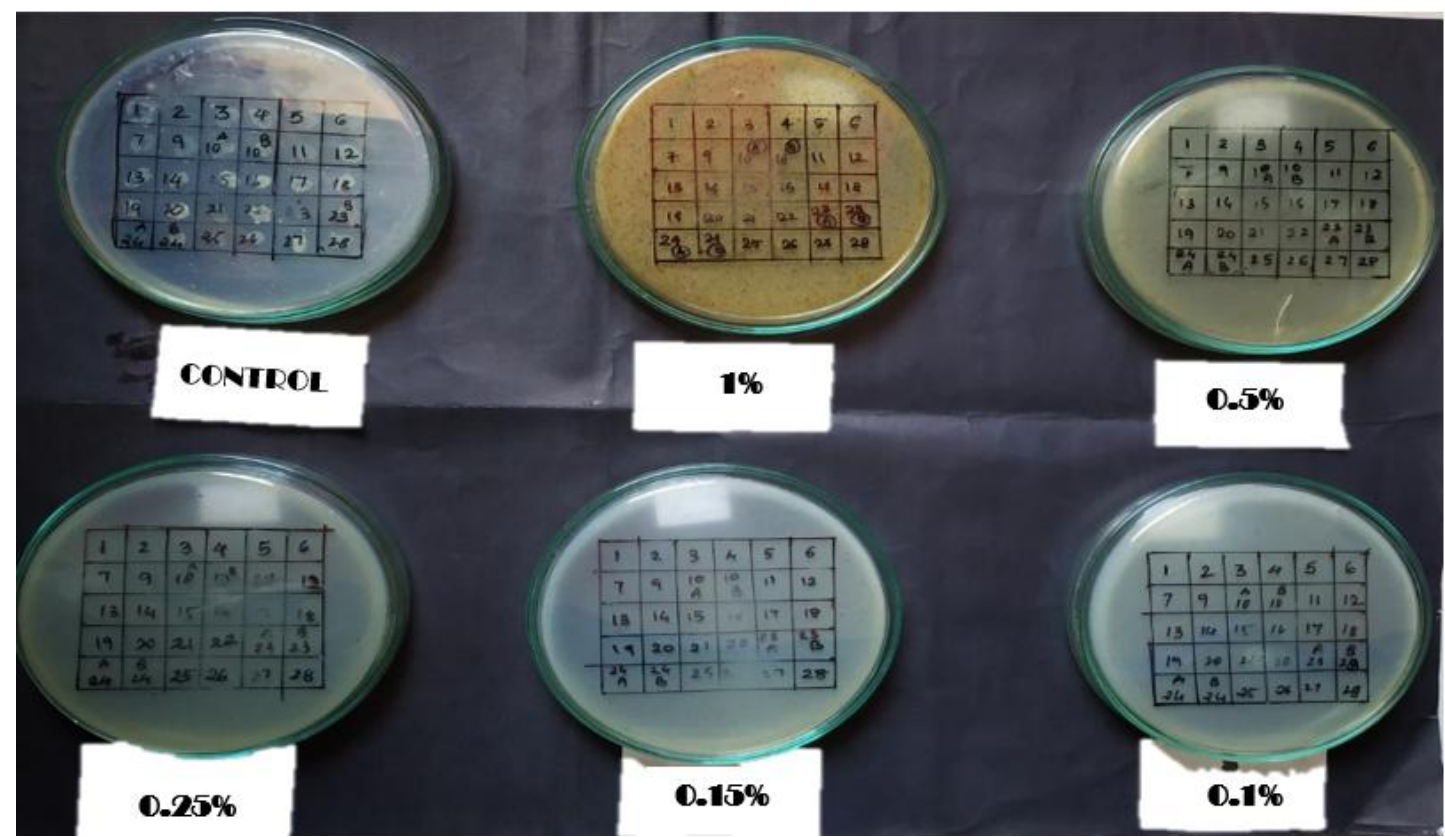

Figure 1: Minimum inhibitory concentration of the aqueous leaf extract against the wound isolates by grid plate method

Table 4: MIC of the different extracts

\begin{tabular}{|c|c|c|c|c|c|c|}
\hline \multirow{2}{*}{ Organism } & \multicolumn{3}{|c|}{ MIC of acetone extracts $(\mathrm{g} \%)$} & \multicolumn{4}{|c|}{ MIC of aqueous extracts $(\mathrm{g} \%)$} \\
\cline { 2 - 7 } & Seed & Bark & Leaf & Seed & Bark & Leaf \\
\hline Staphylococcus spp. $(\mathrm{n}=6)$ & 0.25 & 0.15 & $>1.0$ & $>1.0$ & $>1.0$ & 0.1 \\
\hline Streptococcus spp. $(\mathrm{n}=3)$ & $>1.0$ & 1.0 & $>1.0$ & $>1.0$ & $>1.0$ & 0.1 \\
\hline Escherichia spp. $(\mathrm{n}=4)$ & $>1.0$ & 0.1 & $>1.0$ & $>1.0$ & $>1.0$ & 0.1 \\
\hline Klebsiella spp. $(\mathrm{n}=4)$ & $>1.0$ & 1.0 & $>1.0$ & $>1.0$ & $>1.0$ & 0.1 \\
\hline Proteus spp. $(\mathrm{n}=4)$ & $>1.0$ & 1.0 & $>1.0$ & $>1.0$ & $>1.0$ & 0.1 \\
\hline Pseudomonas spp. $(\mathrm{n}=4)$ & $>1.0$ & 1.0 & $>1.0$ & $>1.0$ & $>1.0$ & 0.1 \\
\hline Kluyvera spp. $(\mathrm{n}=5)$ & $>1.0$ & 0.1 & $>1.0$ & $>1.0$ & $>1.0$ & 0.1 \\
\hline
\end{tabular}

Vinoth B et al., ${ }^{22}$ (2012) also reported better activity of aqueous leaf extract against $S$. aureus. The acetone extract of leaves of Moringa oleifera Lam. were significantly low in antimicrobial activity was reported by Sundar S et al., ${ }^{23}$ (2014).

\section{Conclusions}

Wound infections are the most common hospital acquired infections and can be treated with conventional drugs, but the overuse of these drugs has led to the development of 
multiple drug resistant pathogens and making it difficult to treat. Plants have been used since ancient times for treatment of various diseases since they are a rich source of phytochemicals which possesses antibacterial, anticancer, antifungal properties etc. In the present study, the aqueous and acetone extract of leaf, bark and seeds of Moringa oliefera Lam. were analysed qualitatively and quantitatively for in vitro antimicrobial activity against wound pathogens. The aqueous leaf extract had broad spectrum activity with a significantly better antimicrobial activity against both Grampositive and Gram-negative pathogens. The aqueous leaf extract was active against both MDRs and non-MDRs and thus proved to have potential to be used as a therapeutic agent.

\section{References}

[1] Coker M, Adejo G, Emikpe B, Oyebanji V, "Evaluation Of The Wound Healing Potential of Ointment Preparation Of Ethyl-Acetate Extract Of Moringa oleifera Lam. (Lam) In Rats" African Journal of Traditional Complementary and Alternative Medicines, 15 (3)(2018): 64-71

[2] Mohammed A, Seid M E et al., "Bacterial Isolates and Their Antimicrobial Susceptibility Patterns of Wound Infections among Inpatients and Outpatients Attending the University of Gondar Referral Hospital, Northwest Ethiopia” International Journal of Microbiology(2017).

[3] Egbe C A, Omeregie R, Igbarumah I O, Onemu S, "Microbiology of Wound Infections and its Associated Risk Factors among Patients of a Tertiary Hospital in Benin City, Nigeria" Journal of Research in Health Sciences, 11(2), (2011), 109-113

[4] Dave K, Shah H, Patel K G, "Antibacterial Activity and Phytochemical Analysis of Methanolic and Acetonic Extracts from Moringa oleifera Lam., Vitex negundo and Rosa indica." International Journal of Current Microbiology and Applied Sciences, 7(7), (2018), 3718-3727.

[5] Saadabi A M, Zaid I E A, "An In vitro Antimicrobial Activity of Moringa oleifera Lam. L. Seed Extracts Against Different Groups of Microorganisms." Australian Journal of Basic and Applied Sciences, 5(5), (2011), 129-134.

[6] Nepolean P, Anitha J, Renitta R E, "Isolation, analysis and identification of phytochemicals of antimicrobial activity of Moringa oleifera Lam. Lam." Current Biotica, 3(1), (2009).

[7] Ma Z F, Ahmad J et al., "Evaluation of phytochemical and medicinal properties of Moringa (Moringa oleifera Lam.) as a potential functional food" South African Journal ofBotany, (2018).

[8] Bergey's DH: bergey's manual of systematic bacteriology vol-1, edited by N R Krieg and J G Holt; Based on bergeys manual of determinative bacteriology classification II, (1987).

[9] Bauer AW, Kirby WM, Sheries J.C. and Turuck M; antibiotic susceptibility testing by standard single disc method. Amj pathology; 45, (1996), 433-496.

[10] A. Sofowara; Medicinal Plants and Traditional Medicine inAfrica, Spectrum Books, Ibadan, Nigeria, (1993).
[11] C. M. Ejikeme, C. S. Ezeonu, and A. N. Eboatu, "Determination of physical and phytochemical constituents of some tropical timbers indigenous to Niger Delta Area of Nigeria, " European Scientific Journal, vol. 10, no. 18, (2014), pp. 247-270.

[12] H. Hikino, Y. Kiso, H. Wagner, and M. Fiebig, "Antihepatotoxic actions of flavonolignans from Silybum marianum fruits," Planta Medica, vol. 50, no. 3, (1984), pp. 248-250.

[13] Indian Pharmacopoeia. Govt. of India, Ministry of Health and Family Welfare, India, 2(2), (2007), 11- 59.

[14] Mama M, Alemsegad A, Sewunet T, "Antimicrobial susceptibility pattern of bacterial isolates from wound infection and their sensitivity to alternative topical agents at Jimma University Specialized Hospital, South-West Ethiopia" Annals of Clinical Microbiology and Antimicrobial, 13:14, (2014).

[15] Taiwo S S, Okesina A B, Onile B A, "Invitro antimicrobial susceptibility pattern of bacterial isolates from wound infection in University of Ilorin teaching hospital" African Journal of Clinical and Experimental Microbiology, Vol 3(1), (2002).

[16] Mordi R M, Momoh M I, "Incidence of Proteus species in wound infections and their sensitivity pattern in the University of Benin Teaching Hospital." African Journal of Biotechnology Vol. 8 (5), (2009), 725-730.

[17] Bessa L J, Fazii P, Giulio M D, Cellin L, "Bacterial isolates from infected wounds and their antibiotic susceptibility pattern: some remarks about wound infection." International Wound Journal ISSN 17424801, (2013).

[18] Biadglegne F, Abera B et al., "Bacterial isolates from wound infection and their antimicrobial susceptibility pattern in FelegeHiwot Referral Hospital, North West Ethiopia." Ethiopia Journal of Health Sciences, Vol 19 (3), (2009).

[19] Padmalochana K "Anti-inflammatory activity and phytochemical analysis of Moringa oleifera Lam. ethanol and acetone leaves extract." Journal of Drug Delivery \& Therapeutics., (2018), 8(6):269-273.

[20] Javed K Z, Ahemd K N, Imrana N, Shahab N, "Exploration of physicochemical and phytochemical potential of Moringa oleifera Lam. Lam (Sehjana) fruits/pods." Journal of Drug Delivery \& Therapeutics., (2018), 8(6):213-220.

[21] Rathi B, Patil P A, Baheti A M, "Evaluation of aqueous extract of pulp and seeds of Moringa oleifera Lam. for wound healing in albino rats." Journal of Natural Remedies, (2004), 4(2): 145-149.

[22] Vinoth B, Manivasagaperumal R, Balamurugan S, "Phytochemical Analysis and Antibacterial Activity of Moringa oleifera Lam. Lam." International Journal of Biological Sciences, 2(3), (2012), 98-102.

[23] Sundar S, Anush L, Hema P et al., "Comparative study of anti-bacterial activity of bark, leaves and flesh extracts of MoringaL." International Journal of Allied Medical Sciences and Clinical Research, Vol 2 (3), (2014). 